\title{
Correction to: Self-Evaluative Scientific Modelling in an Outreach Gene Technology Laboratory
}

\author{
Tamara Roth $^{1} \cdot$ Franz-Josef Scharfenberg ${ }^{1} \cdot$ Julia Mierdel $^{1} \cdot$ Franz X. Bogner ${ }^{1}$
}

Published online: 26 August 2020

(C) Springer Nature B.V. 2020

\section{Correction to: Journal of Science Education and Technology} https://doi.org/10.1007/s10956-020-09848-2

The original version of this article unfortunately contained a mistake. Presented here are the correct Figs. 1, 2 and 3.

The original article has been corrected.

Publisher's Note Springer Nature remains neutral with regard to jurisdictional claims in published maps and institutional affiliations.

The online version of the original article can be found at https://doi.org/ 10.1007/s10956-020-09848-2

Tamara Roth

tamara.roth@uni-bayreuth.de

1 Centre of Math \& Science Education, Department of Biology Education, University of Bayreuth, Universitätsstr. 30 NW I, 95447 Bayreuth, Germany 
Fig. 1 a Repeated measurement design of both instructional variants in the outreach lab. $b$ Item-difficulties for $\mathrm{T} 0$ and $\mathrm{T} 1$. DNA-related items shortened "D", model-related items shortened "M". Item examples shown in Table 3 highlighted in light grey (note the shift between the pre- and post-schedule)
Fig. 2 Changes in overall knowledge scores for both modellers- 1 and modellers-2. All participating groups increased their actual learning success scores: $(\mathrm{T} 1$ - T0) x $(\mathrm{T} 1 / 30)$. Persistent learning success scores: (T2 - T0) x (T2/30), however, dropped in comparison to actual learning success scores
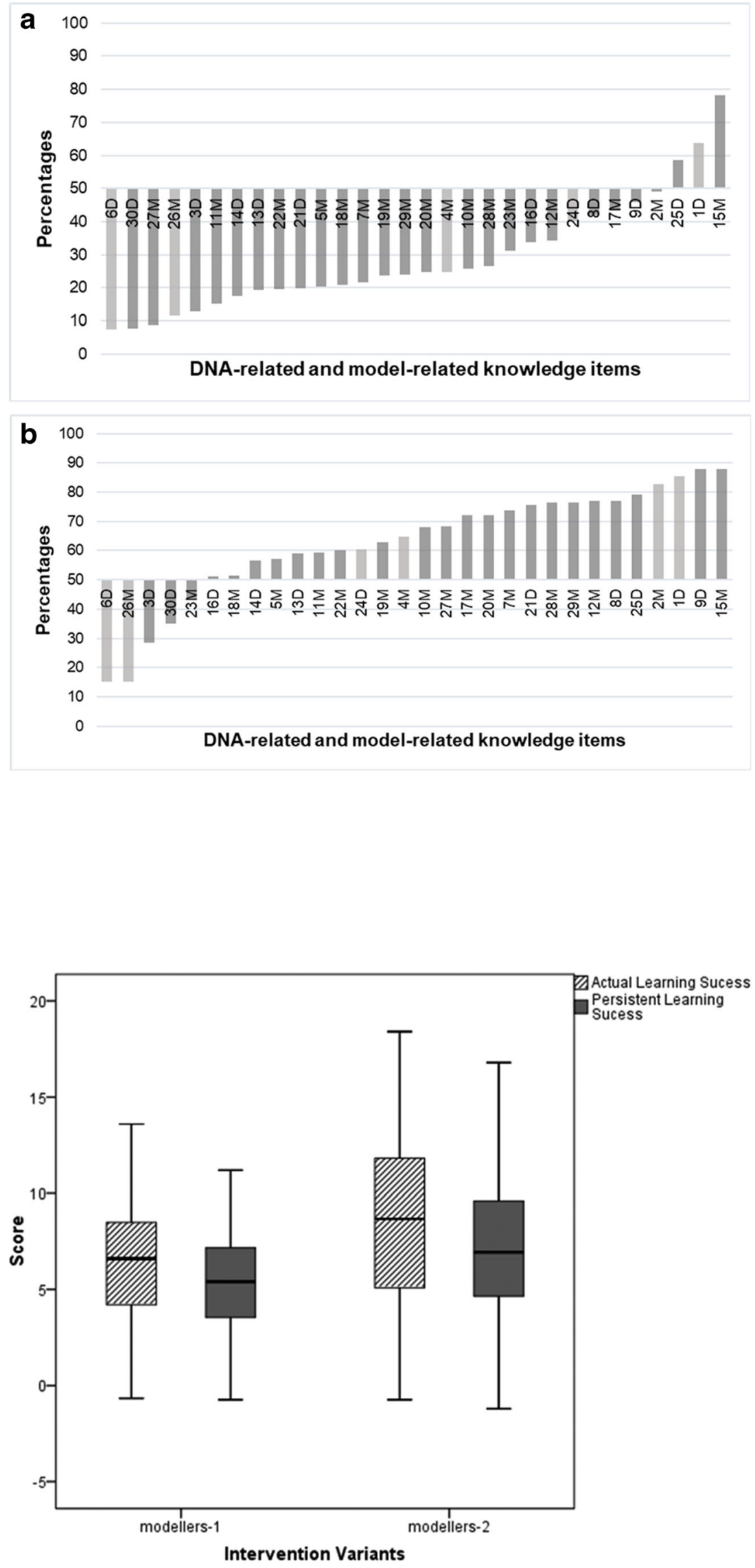
Fig. 3 Changes in all 18 modelrelated knowledge items for both modellers-1 and modellers- 2 . All participating groups increased their actual learning success scores: (T1 - T0) x (T1/18). Persistent learning success scores: (T2 - T0) x (T2/18), however, dropped in comparison to actual learning success scores

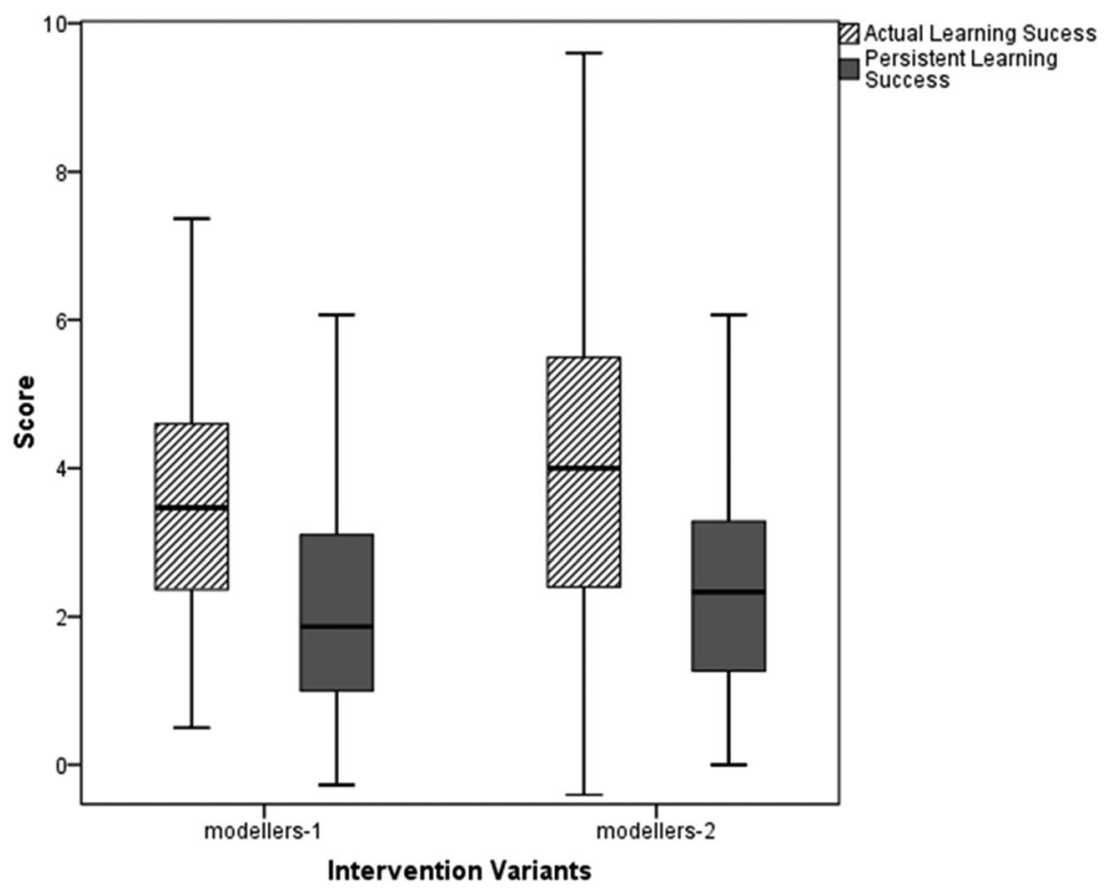

